\title{
PART 5. \\ ILLEGAL CROSSINGS OF THE POLISH-CZECHOSLOVAK BORDER AND CARPATHIAN UKRAINE
}

The news that Transcarpathia had become autonomous were received with great enthusiasm in Eastern Galicia. As for the first responses of Ukrainian political organizations in Galicia concerning the autonomy claims of the Transcarpathians, they began to appear since mid-September 1938. The reason for their appearance were intensive actions of the Ukrainian Central Peope's Republic in the matter of granting autonomy to Subcarpathia, in particular, sending on September 8, 1938 a delegation led by A. Voloshyn to Prague and the ever-growing international tension around Czechoslovakia concerning the Sudeten-German question.

On September 16, 1938, the PUN (Leadership of Ukrainian Nationalists), which had a wide illegal network in Galicia, spread the call: "The Ukrainian Transcarpathia defends at this moment the idea of an independent Ukrainian Transcarpathian state, which with a moment of explosion of uprising in all Ukrainian lands against all Ukrainian occupiers spontaneously unites the state of all Ukrainians"412. At that time, the chairman of the PUN, A. Melnyk, recalled: "The first days of my re-enlistment of the agencies were fervent measures to help Carpathian Ukraine, all our forces and the means at our disposal were directed there" ${ }^{\text {"13. }}$.

The Ukrainian National Democratic Union, headed by D. Levytsky, expressed its attitude to the Transcarpathian events. On September 20, 1938, in Lviv, at a meeting of the Central Committee of Ukrainian National Democratic Alliance, it was proclaimed: "In the historic moment of political self-determination of the peoples who inhabit Czechoslovakia, the struggle of Ukrainians to exercise the right of self-determination cannot be neglected against their will by

\footnotetext{
412 Діло. 1938. 2 жовтня.

413 Ольжич О. Незнаному Воякові. Заповідане живим. К.: Фундація імені О. Ольжича, 1994. С. 33.
} 
any committed facts. Therefore, Central Committee of the Ukrainian National Democratic Alliance congratulates Transcarpathian Ukrainians in their competitions for the exercise of their rights in all Ukrainian ethnographic lands of Transcarpathia, which are in the interest of the whole Ukrainian people"414.

On September 25, 1938 a meeting initiated by the leader of the National Unity Front, D. Paliiev, took place in the premises of the Ukrainian society "Sokil" in Lviv on the occasion of the Transcarpathian events. According to the Polish police, about 200 people took part in it, and the UNDO body - the weekly "Svoboda" reported that there was a thousand people present ${ }^{415}$. After the meeting there was a demonstration under the slogans "Long live Ukraine", "Shame on Czechs, Poles and Magyars", "Long live Transcarpathian Ukraine". Police stopped the demonstrants at Galytska Street; Polish students, who took part in the skirmish, beat several protesters ${ }^{416}$. A day earlier, a demonstration of Ukrainian students in support of Transcarpathia took place in Lviv ${ }^{417}$. On October 30, 1938 a demonstration was organized by the local OUNmembers in Busk, initiated by D. Kupiak and H. Pryshliak ${ }^{418}$.

Immediately after the Munich Conference, there is a rapprochement between Poland and Hungary in the Transcarpathian issue. It was at this time that the representative of the Hungarian Ministry of Foreign Affairs, I. Csaky, negotiated with the Polish Minister of Foreign Affairs J. Beck on the Polish-Hungarian cooperation. Polish radio and press began a blatant anti-Ukrainian propaganda, and Polish government decides to secretly support terrorist war in Transcarpathia ${ }^{419}$. All this forced the Central Committee of the Ukrainian National Democratic Alliance to make a statement on 8 October, 1938 to Polish Prime Minister F. SlavojSkładowski and Foreign Minister J. Beck. The Polish government in

\footnotetext{
414 Центральний державний історичний архів України у Львові (далі - ЦДІАУ

у Львові). Ф. 205. Оп. 1. Спр. 493. Арк. 198.

${ }^{415}$ ЦДІАУ у Львові. Ф. 205. Оп. 1. Спр. 493. Арк. 198.

416 Діло. 1938. 2 вересня.

417 Діло. 1938. 15 жовтня.

418 Куп'як Д. Спогади нерозстріляного. Торонто - Нью-Йорк, 1991. С. 70-71.

419 Діло. 1938. 16 жовтня.
} 
the Transcarpathian case took a position contrary to the idea of selfdetermination and became involved in advocacy work for the accession of Transcarpathia to Hungary. This policy was actively supported by the Polish Telegraph Agency and radio. News about giving autonomy to Subcarpathian Rus' quickly reached Galicia. A wave of rallies and demonstrations swept through the country. The vast majority of them were initiated by the OUN. R. Shukhevych, who arrived in Lviv in October 1938, was especially active ${ }^{420}$. On October 11, 1938 a church service was held at the Greek Catholic Cathedral in Yaroslav ${ }^{421}$. On October 14, a festive gathering was held in the church of the Basilian Fathers in Przemysl, initiated by UNDO members, followed by a demonstration under the slogans "Long live Ukraine", "Get away with the Poles, get away with the Magyars". The protest was stopped by a reinforced police department. Metropolitan of Galicia and Archbishop of Lviv Count Andrey Sheptytsky also expressed his congratulations and best wishes ${ }^{422}$. On October 11, the Lviv newspaper "Dilo" reported that "on the shoulders of the leaders of the Ukrainian Subcarpathia, history has put a huge task and we sincerely wish that they would fulfil it with honor and success - to preserve the Ukrainian Subcarpathia for its natives" $"$. On October 13 a telegram of the following content was sent to the editorial office of "Nova Svoboda": "The Ukrainian National Council and the first government of Subcarpathian Rus' recieved a sincere wish for complete success in the fight against the Hungarian threat. The telegram was signed by the leaders of several legally existing political organizations of Galicia - D. Paliiv, Rudnytska, Starosolskyi, Stakhiv" ${ }^{\text {"24. }}$

Throughout the short-lived existence of Carpathian Ukraine, Transcarpathians have been constantly receiving moral support from both the various organizations of Galicia and its individual citizens. On November 19, 1938 members of the Lviv Political College, who met in Danzig, also discussed the question of assistance to Carpathian

\footnotetext{
${ }^{420}$ ЦДІАУ у Львові. Ф. 205. ОП. 1. Спр. 494. Арк. 52.

${ }^{421}$ ЦДІАУ у Львові. Ф. 205. ОП. 1. Спр. 494. Арк. 51.

422 Діло. 1938. 11 жовтня.

423 Ibid.

${ }^{424}$ ДАЗО. Ф. 3. Оп. 2. Спр. 5. Арк. 3.
} 
Ukraine. They came to the conclusion that "Galicia could send out cooperators, teachers, engineers and drivers" ${ }^{\prime 425}$. O. Dumin wrote in a letter to A. Voloshyn: "1) what specialists does Carpathian Ukraine need? 2) in what quantity of the above named professions? 3) what roads would they need to get to Carpathian Ukraine? Straight through the mountains, or through Germany, Slovakia, the Czech Republic?"426. It is unknown whether A. Voloshyn responded to O. Dumin's letter. As for O. Dumin, he "was in close contact with the German secret service. He was also a member of the German Institute

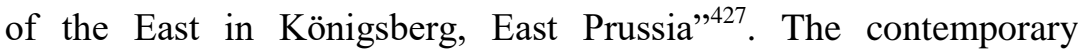
researcher V. Kosyk wrote that in his time O. Dumin "constantly dreamed of various intrigues" against E. Konovalets, for which he was expelled from UVO (Ukrainian Military Organization) in 1925. In 1938 he was not a member of the OUN, which he wrote in a letter to A. Voloshyn. In February 1939, the Ukrainian Central People's Republic published in "Nova Svoboda" the appeal "To all Ukrainians in their native lands and in the scattered lands" $" 428$. A separate statement was annexed to the request of the Ukrainian Central People's Republic and the autonomous government of Carpathian Ukraine.

Support for A. Voloshyn's government has been revealed in hundreds of letters authored by Galicians. They wrote about their willingness to help build a young autonomous country with all their powers and experience. Galician Orest Zozulia asked to let him be enrolled in the main financial department in Khust ${ }^{429}$. The request to serve Carpathian Ukraine was expressed by the Galicians Ivan Holyk, Anton Mysyshyn, Teodor Fedus', Toma Datskiv, Ivan Mikhailiuk. Former UGA (Ukrainian Galician Army) warrior Omelian Lysniak, who lived in Presov, wrote: "I, the undersigned... dare to offer my services in order to further serve my people" ${ }^{\$ 30}$. Many UGA soldiers

\footnotetext{
ДАЗО. Ф. 3. Оп. 3. Спр. 173. Арк. 15-16.

ДАЗО. Ф. 3. Оп. 3. Спр. 173. Арк. 17.

427 Косик В. Україна і Німеччина у другій світовій війні. Париж - Нью-Йорк Львів, 1993. С. 46.

${ }^{428}$ Нова свобода. 1939. 15 лютого.

429 ДАЗО. Ф. 3. Оп. 3. Спр. 173. Арк. 19.

430 ДАЗО. Ф. 3. Оп. 1. Спр. 9. Арк. 1.
} 
were forced to emigrate abroad after the defeat of the liberation struggle and lived in Czechoslovakia, Germany, England, USA in the late 1930s. Ivan Vovk wrote from France that he would be useful to Carpathian Ukraine as an engineer. He had a working experience "on the railways, or on electric power stations, or related industries" Ivan Tsymbal, from Pidhaitsi, offered his services as a former "member of the military police in Ternopil" and who "was honored as a very skillful shooter" 432 .

Many Galicians found themselves in the Hungarian-occupied territory after the decisions of the Vienna Arbitration. They asked to help them to get to Khust. It should be noted that Galician writer V. Birchak helped many of them. In particular, he contributed to the return to Carpathian Ukraine of Ivan Ferenc, a former UGA shooter who at one time participated in the battles for Kyiv ${ }^{433}$. Hundreds of Galicians appeared in Transcarpathia in the 1920-30's. They were also mainly involved in the development of autonomous Transcarpathia in different areas of economic life. V. Latsanych wrote about the Galician writer Kost' Vahylevych, who lived in Rakhiv: "...he knows the local circumstances and is very desirable..." ${ }^{\circ 34}$.

In March 1939, that is, on the eve of the opening of the Soim of Carpathian Ukraine, Olena Kysilevska from Kolomyia wrote to A. Voloshyn: "Let me congratulate you, as a father of the people, sincerely on the opening of the first Carpatho-Ukrainian Soim and on the occasion of this joyous for all Ukrainians wave to express my wishes for even greater success, even greater victory"435. Galicians, who were a part of the organization "Young Ukraine", on March 5, 1939 wrote from Paris: "Good luck to you, God, Stonecutters of Transcarpathia! You start a work on the great day of Shevchenko's anniversary. The spirit of our Prophet will bless you for the work of building of a "free, new family", and every Ukrainian heart will share with you the happiness and joy of an unforgettable March 9, 1939.

431 ДАЗО. Ф. 1148. Оп. 1. Спр. 293. Арк. 1.

432 ДАЗО. Ф. 17. Оп. 2. Спр. 5. Арк. 6.

433 ДАЗО. Ф. 3. Оп. 1. Спр. 343. Арк. 1.

434 ДАЗО. Ф. 3. Оп. 3. Спр. 92. Арк. 1.

435 ДАЗО. Ф. 3. Оп. 2. Спр. 5. Арк. 2. 
Long live Ukraine!" ${ }^{436}$. A bright illustration of the general upliftment that encompassed the Galicians was the greeting letter from A. Sheptytsky to A. Voloshyn.

At the end of 1938 mass transitions of the Polish-Czech border began. "Young people, mostly peasant boys, spontaneously come from Galicia" - V. Grendzha-Donsky wrote in his diary ${ }^{437}$. The Sich Border Guard constantly reported to Carpathian government: "Ukrainian fugitives from Poland have been detained in Sabinow. They ask to let them go to Uzhgorod" ${ }^{\text {"438 }}$. This process intensified after the announcement of the order to create the Carpathian Sich. Lviv magazine "Na Perelomi" ("At the Turn") argued that "in Sich itself there are many Ukrainian emigrants from outside the Carpathian Ukraine, ${ }^{, 439}$.

It is impossible to answer the question of when the first such crossing of the Polish-Czech border took place. Analyzing the materials of the Transcarpathian and Galician press, separate archival materials, we can assume that the beginning of illegal border crossings should not be associated with the appointment of A. Voloshyn as the Prime Minister of the Autonomous Government. They started much earlier. This is evidenced in the memories of I. Stebelsky, an active participant in the national liberation struggle of 1938-1939 $9^{440}$.

On October 23, 1938 the Lviv newspaper "Nedilia" wrote: "Within a few days, attempts to cross the border into Subcarpathian Rus' began. V. Marchuk, L. Petrov, V. Lesiv and D. Tepa were detained in the Lavochne district" ${ }^{\prime 41}$. And already on October 31 the district prosecutors received the letter from the prosecutor of the Court of Appeal in Lviv, J. Khirovsky, which began with the words: "In recent times, there have been frequent cases of Polish Ukrainians

\footnotetext{
436 Діло. 1938. 30 листопада.

437 Гренджа-Донський В. Щастя і горе Карпатської України: Щоденник. Мої спогади / Ред. Д.М.Федака. Ужгород: ВАТ «Видавництво «Закарпаття», 2002. С. 318.

438 ДАЗО. Ф. 3. Оп. 2. Спр. 5. Арк. 3.

${ }^{439}$ На переломі. 1939. Ч. 6.

440 Стебельський I. Шляхами молодості й боротьби. Спогади. Статті. Листування. К.: «Смолоскип», 1999. С. 19-20, 27.

${ }^{441}$ Неділя. 1938. 23 жовтня.
} 
being detayned for the illegal crossing of the Polish border in the direction to Czechoslovakia, and more specifically to the territory of the Transcarpathian Rus",442. This words were followed by recommendations on what to do in such cases. Not very possible occurrence of such a document indicates that as early as November 1, 1938, the Prosecutor of the Court of Appeal reported to the Prosecutor's Office of the Ministry of Justice in Warsaw about sending letters of recommendation ${ }^{443}$. On the same day, a supplement to the letter of October 31 was sent from Lviv to the district prosecutors $^{444}$. Reports of illegal border crossings began to come from district courts in Lviv. In one of them (a letter from the prosecutor of the district court in Berezhany, dated November 30,1938 ) we find the date of one of the first recorded crossings of the Polish-Czech border: "On October 20, they (a group of three Ukrainians) crossed the border near the village Rozanka of Stryi district" ${ }^{\prime 45}$.

What was the reason for these illegal border crossings? First, in contrast to the Polish reality, the very existence of subcarpathian autonomy, in which Galician Ukrainians saw from the very beginning a small germ of their dreams of Ukrainian statehood, and therefore tried, though to some extent, to make their efforts to build it. The appeal for cooperation of all Ukrainians, that was made by the Ukrainian Central People's Republic, published in "Nova Svoboda" on October 21, 1938, played an important role ${ }^{446}$. However, it must be noted that the Ukrainian Central People's Republic was referring to individual experts, not to massive border crossings.

Considering the problem of border crossings, we closely approach the question of the proportion of their spontaneity and organization. Legal political organizations could not take part in such an action, that's why only OUN can be treated as an organizer. For the Polish political and judicial authorities the answer was unambiguous: "The data of the police and the Border Guard Service conclude that the

\footnotetext{
${ }^{442}$ ЦДІАУ у Львові. Ф. 205. Оп. 1. Спр. 1095. Арк. 8.

${ }^{443}$ ЦДІАУ у Львові. Ф. 205. ОП. 1. Спр. 879. Арк. 97.

${ }^{444}$ ЦДІАУ у Львові. Ф. 205. Оп. 1. Спр. 1075. Арк. 11.

445 ЦДІАУ у Львові. Ф. 205. ОП. 1. Спр. 1095. Арк. 6.

${ }^{446}$ Нова свобода. 1938. 21 жовтня.
} 
escalation of border violations in the described cases is due to the hostile to Poland action of Ukrainian organizations, which under the influence of international events have recently acted more bravely and intensive against Poland's interests, and the activity of illegal transition of Ukrainian youth to Transcarpathian Rus' is ruled by the OUN (From a letter from the Prosecutor of the Court of Appeal in Lviv of October 31, 1938)" "447. However, it should be noted that this statement was a clear exaggeration. From D. Kupiak's memoirs it is clear that as of November 1938 "there was no official permission for OUN members from the OUN Leadership to move to Carpathian Ukraine" ${ }^{, 48}$. In our opinion, the main reason for illegal border crossings was the desire of Galician Ukrainians to contribute to the construction of an independent Carpathian Ukraine. This is what they most sought in Eastern Galicia. Therefore, the element of spontaneity greatly outweighed the organizational and disciplined crossing of the Polish-Czechoslovak border. "The events in Carpathian Ukraine," recalled D. Kupiak, "caused admiration among all the Ukrainian people, wherever they lived. The people believed that a new period of their history was coming" 449 .

The Czechoslovak government was hostile to illegal border crossings. There are hundreds of eyewitness accounts when border guards arrested the defectors and after some time, or immediately, turned them back. Also important was the fact that many Polish spies and terrorists who spoke Ukrainian fluently crossed the border. Describing the transition through the Carpathians, V. Onufryk stated that he himself initiated the organization of a marching group of seven people. Later, day after day wandering in the mountainous regions, they reached Subcarpathian Rus', where they were sometimes taken as Polish terrorists ${ }^{450}$. Polish terrorists, crossing the border, often masked themselves as Ukrainians. M. Bazhanskyi wrote about the detention of such a group of terrorists in his memoirs ${ }^{451}$.

\footnotetext{
${ }^{447}$ ЦДІАУ у Львові. Ф. 205. Оп. 1. Спр. 1075. Арк. 8.

${ }^{448}$ Куп'як Д. Спогади нерозстріляного. Торонто - Нью-Йорк, 1991. С. 74.

${ }^{449}$ Ibid. C. 68.

${ }^{450}$ Онуфрик В. Спомин з Карпатської України. 1938-1939. Торонто - Ужгород, 1995. С. 55.

${ }^{451}$ Бажанський М. Мемуарна мозаїка. К.: Критика, 1998. С. 114-115.
} 
The Czechs were really suspicious of border guards, fearing not so much the young men and girls from Galicia as the masked Polish terrorists. Great material about the devastating actions of Polish terrorists is contained in V. Grendzha-Donsky's diary ${ }^{452}$. Despite the not always favorable attitude of the Czechs to the illegal border crossings from Galicia to Carpathian Ukraine, even among them there were people who were looking at this mass phenomenon through their fingers. These include J. Ruschak, who later resided in Karlovy Vary. Undoubtedly, the fate of many Galicians depended on him to some extent ${ }^{453}$.

Many defectors were detained by Polish border guards and were immediately taken to the court. On April 25, 1939 a Polish court in Sambir sentenced Ivanna Grytsyliak, a peasant from the village of Barych, in the Przemysl County, to one year in prison. It was enough for the Polish authorities to have only one letter from this girl that she wrote to her fiancé ${ }^{454}$. Often Galician youth crossed the border in groups and not always successfully. In Berezhany during the three weeks a trial of 28 Ukrainians of Bobrech and Khodoriv lands took place, 16 of whom were sentenced to between 2 and 8 years in prison $^{455}$. It should be added that it was especially dangerous to cross the border with OUN members. In this case, the term was significantly increased. The groups of OUN members were set up in Galicia, who were tasked with recruiting volunteers and helping them navigate through the Carpathians. It is for this reason that the Stanislaviv Court sentenced V. Melnychuk and P. Ksendziuk ${ }^{456}$. Y. Solovchuk, Y. Odonii, D. Myketchuk, S. and P. Veredyuk were charged for the same crime ${ }^{457}$. The Polish "district court in Stryi considered the case of Markiyan Kravchuk, Lev Sorochan, Petro Hlushko, Volodymyr Parij, Ivan Dizenko, Yakiv Maksymets, all from

\footnotetext{
452 Гренджа-Донський В. Щастя і горе Карпатської України: Щоденник. Мої спогади / Ред. Д.М.Федака. Ужгород: ВАТ «Видавництво «Закарпаття», 2002.

${ }^{453}$ Вони боронили Карпатську Україну: Нариси історії національно-визвольної боротьби закарпатських українців /М.М. Вегеш, М.В. Делеган, О.Д. Довганич та ін. [Відп. ред. М.М.Вегеш]. Ужгород: Карпати, 2002. С. 320.

454 Діло. 1939. 4 травня.

455 Діло. 1939. 11 червня.

456 Діло. 1939. 27 червня.

457 Діло. 1939. 15 лютого.
} 
Perehinsk, distr. Dolyna, and Vasyl Slavynsky from Pidnistria"458. They were sentenced to one year in prison. Such facts are cited by the newspaper "Dilo"459. "Nova Svoboda" reported that “...in Sambir, three girls are being judged: Maria Menzynska, Maria Nyzhnyk and Theophilia Jaworska. They are accused for the connections with OUN"460. "The court in Stanislaviv," is said in another post, "condemned the illegal transfer to Carpathian Ukraine of 14-year-old high school student P. Sovij, 18-year-old... D. Demchyshyn for 10 months in prison and M. Kalytyk from Kolomyia for 6 months in prison"461. We also find the verdict for members of the OUN Volodymyr Bilaniuk, Mykhailo Klebus, Yurko Wenher, Stepan Zelsky ${ }^{462}$ " "Nova Svoboda" wrote about the trial of 35 OUN members ${ }^{463}$.

There have been numerous cases when, in addition to "own" years or months of imprisonment, defectors have also been deprived of their civil rights. In particular, the Stryi court considered the case of R. Kundrat, S. Zavadka, V. Poryk, D. Holovchan, F. Kipash, M. Spalyn, Y. Melen', D. Kovalev and I. Kishchuk. All of them got between half and two years in prison and were deprived of their civil rights for three to five years. ${ }^{464}$. On April 4, 1939 J. Kabarovskyi, E. Lytynskyi and L. Klyn were sentenced in Lviv, respectively, to one, six and one and a half years of imprisonment for hiding and assisting the Ukrainians during the crossing of the Polish-Czech border on October 25, $1939^{465}$.

In November 1938 in order to avoid new lawsuits, the government of A. Voloshyn issued an advertisement "Against Unreasonable Emigration", which was published immediately by all Ukrainian newspapers. However, the illegal border crossings did not stop. Other warnings appeared one by one. A similar statement, called "Beware of light-hearted emigration", was circulated by the Ukrainian Press

\footnotetext{
${ }^{458}$ Ibid.

459 Діло. 1938. 16 грудня.

${ }^{460}$ Нова свобода. 1939. 7 березня.

${ }^{461}$ Нова свобода. 1939. 25 лютого.

462 Нова свобода. 1939. 14 вересня.

${ }^{463}$ Нова свобода. 1938. 11 жовтня.

464 Жіноча воля. 1939. Ч. 2.

465 ЦДІАУ у Львові. Ф. 205. Оп. 1. Спр. 1089. Арк. 17-19.
} 
Service in Berlin ${ }^{466}$. V. Grendzha-Donsky wrote about such cases: "These fugitives are in danger, because the Czech gendarmerie catches and simply sends them back without telling us. There have also been cases when they have been transfered to the Poles, and the Poles punished them severely"467. Among the Polish reports to the Prosecutor of the Court of Appeal in Lviv, we can read that "they (three Galicians who illegally crossed the Polish-Czech border Aut.) went to Pryslip, where they surrendered to the Czech border guards, who sent them to the gendarmerie in Torun, then to Volove, and then to Khust into the military secret service. They were interrogated there as to whether they knew about the organization of the Polish army, whether there were troops on the border, whether they were mobilizing, whether they considered themselves Poles or Ukrainians. They were locked up in a prison where there were other Polish Ukrainians. Fifteen in total. On November 12, everyone was escorted to Volove, and on November 13, they were taken by car to the border and handed over to Polish border guards in Mishkov. From there they were sent to the district prosecutor's office in Stryi",468.

What is the position of the PUN in relation to the mass illegal crossings of the Polish-Czech border? At the beginning the PUN initiated them, then after a while, and especially after the warnings were published in Ukrainian newspapers, it changed its position. "The people of work were needed in Carpathian Ukraine," Z. Knysh mentioned, "but it was enough of them from the leading and capable units supplied by the OUN from their local and emigration staff, and often from the ZUZ (Western Ukrainian Lands - Aut.). The mass transition of ordinary membership created only a troublesome situation for the government of Carpathian Ukraine in internal political relations and threatened with diplomatic conflicts outside. It became clear and undoubtedly after the fall of Carpathian Ukraine that these two or three hundred Galician fighters more or less did not solve anything here" 469 . The government of Carpathian Ukraine was dissatisfied with some members of the OUN, their radical mood.

\footnotetext{
466 Нова свобода. 1938. 11 грудня.

${ }^{467}$ Гренджа-Донський В. Щоденник. Твори. T.VIII. Вашингтон, 1987. С. 80.

${ }^{468}$ ЦДІАУ у Львові. Ф. 205. Оп. 1. Спр. 1095. Арк. 6.

${ }^{469}$ Книш 3. Становлення ОУН. К.: В-во ім. Олени Теліги, 1994. С. 298.
} 
A. Voloshyn asked "not to make a situation in relation to Prague more difficult, to send cultural figures and all kinds of specialists, but not revolutionary screamers, who had already begun to act on the nerves of the local Ukrainian leaders" $"$. A. Voloshyn was also aware of the fact that some members of the OUN were actively involved in the preparation of the upheaval, which resulted in the removal of the members of Carpathian government from power. In this situation, the PUN made the only correct decision: to only send to the territory of Carpathian Ukraine military personnel who had extensive combat experience, as well as the OUN leaders. However, illegal crossings of the Polish-Czech border actually came out of PUN control.

Many Galician Ukrainians were also detained by Polish border guards. Thus, among those Galicians who failed to cross the border and fell into the hands of the Polish prosecutor's office, there were two categories: detained by Polish border guards and handed over to the Poles by the Czech gendarmerie. There was even a separate instruction for the district attorney how to deal with such prisoners: "It is required to resolve such cases as soon as possible. The following issues need to be clarified:

1) for what purpose did the detainee try to cross the border?;

2) in what ways did he get and was he armed?;

3) did he get any help on the road and from whom?;

4) at what point did he have to cross the border and to whom should he come on that side?;

5) was the detainee agitated for illegal emigration.

It is necessary to find out separately whether the detainee belonged to the OUN. Such cases should be reported to the Prosecutor of the Court of Appeal"471. In the letter of the Prosecutor of the Court of Appeal to the District Prosecutor's Offices of November 1, 1938, we can read about the requirement of "a thorough investigation, analysis of all the papers found with the detained, personal considering of the cases. You do not need to treat them with a pattern"472. Particular attention was paid to the agitators: "Persons

\footnotetext{
${ }^{470}$ Химинець Ю. Тернистий шлях до України. Ужгород: МПП «Гражда», 1996. C. 49 .

${ }^{471}$ ЦДІАУ у Львові. Ф. 205. Оп. 1. Спр. 1095. Арк. 6.

${ }^{472}$ ЦДІАУ у Львові. Ф. 205. Оп. 1. Спр. 1095. Арк. 11.
} 
engaged in agitation for illegal crossing of the border are detained on the basis of participation in the action organized by the OUN and are criminally responsible" 473 .

After the creation of the Carpathian Sich, many Galician defectors joined its ranks. The Polish authorities responded quickly. In the instructions of the Prosecutor of the Court of Appeal we can read: "Based on the reports I received from the district prosecutor's offices, it can be said that there is an increasing of number of cases in which persons are detained while attempting to illegally cross the border into the territory of Transcarpathian Rus', trying to cross the border in order to enter "Ukrainian Legion", created in Transcarpathian Rus'..." "Ukrainian Legion" should be treated as a paramilitary organization... Therefore, detainees should be judged under the law on general military service as Polish citizens who, without the consent of the Polish government, enter the military organizations" 474 .

The Polish authorities have repeatedly appealed to the Czechoslovak government with the protest notes, in which they demanded to influence the government of Carpathian Ukraine, which, in their opinion, contributed to the spread of anti-Polish propaganda. Khust authorities, as a rule, denied it. However, such facts have taken place and they have complicated the already difficult situation of the young autonomous country. In the notes of protest of the Polish ambassador, the defectors of the Polish-Czech border were listed as "Ukrainian terrorists". On November 29, 1938 a note of protest from the Polish government was sent to Prague, demanding the immediate return of Kostiantyn Melnyk, Colonel Andriy Melnyk, Mykhailo Bazhazaslavsky, Yevhen Kulchytsky, Volodymyr Zabavsky and Stepan Rosokha. The named persons, most of whom have found shelter in Carpathian Ukraine, were wanted by the Polish government for their involvement in a terrorist attack against Polish Interior Minister B. Pieracki ${ }^{475}$. The Polish ambassador complained that "there can be no good relationship between Poland and Czechoslovakia when the Subcarpathian authorities give permission for staying" to these persons. On November 24, 1938 the Minister of

\footnotetext{
${ }^{473}$ ЦДІАУ у Львові. Ф. 205. ОП. 1. Спр. 1095. Арк. 8.

474 ЦДІАУ у Львові. Ф. 205. Оп. 1. Спр. 1095. Арк. 13.

475 ДАЗО. Ф. 4c/18. Оп. 1. Спр. 51. Арк. 1.
} 
Internal Affairs of Carpathian Ukraine, Y. Revai, and the Director of Police, Y. Biley, demanded from the district governments that "each of these persons should be provided with police care..." and that "these persons should be considered interned"

On December 14, 1938 A. Voloshyn, in a telephone message to the Presidium of the Council of Ministers in Prague, stated that "the protest of the Polish ambassador is based on incorrect information. Dr. Hryts Melnyk, a teacher at a civic school, a Czechoslovak state citizen who lives in Korolevo over the Tysa for many years, and who, as it has been verified, is not involved in any anti-Polish propaganda"477. A. Voloshyn assured Prague that "no anti-Polish propaganda in the territory of Subcarpathian Rus' is under way, and anti-Polish sentiment is caused solely by the fact that terrorists are moving from Poland, and they have Polish military weapons and supplies. It is understood that people cannot be grateful and friendly to neighboring Poland for destroying their property and life" ${ }^{\text {"478 }}$. Such a response by A. Voloshyn did not satisfy the Polish ambassador, who sent a second note of protest on December 28, $1938^{479}$.

In another note of protest, the Polish government demanded the extradition of S. Yuskiv, T. Kapustianskyi, A. Melnyk and H. Stefaniv. A. Voloshyn replied: "We have no Dr. Semen Yuskiv at all, but he is a lawyer in Rakhiv and belongs to the local unit there, as a regular man. He performs no function. We do not have Teophil Kapustianskyi and Andrii Melnyk, and we do not know them at all. We do not have Hnat Stefaniv. In Rakhiv he asked for admission to Sich but was not accepted because he is not our citizen" ${ }^{480}$. In fact, Semen Yuskiv was actually in the territory of Transcarpathia. A lawyer by profession, he was one of the initiators of the Enlightenment movement in Rakhiv. He was noted for his radical views. He considered himself a consistent nationalist.

On December 31, 1938 A. Voloshyn ordered the Director of Police Yu. Biley to make, "within 24 hours, a written report on

\footnotetext{
476 ДАЗО. Ф. 4c/18. Оп. 1. Спр. 51. Арк. 52.

477 ДАЗО. Ф. 3. Оп. 1. Спр. 9. Арк. 2.

478 Ibid.

479 ДАЗО. Ф. 3. Оп. 1. Спр. 12. Арк. 11.

480 ДАЗО. Ф. 3. Оп. 1. Спр. 66. Арк. 3.
} 
whether there were such persons: Bazhanskyi Mykhailo, Alexander Khmeliovskyi, Demchuk Dmytro, Fodchuk Dmytro, Ravich Dmytro, Vretsion Yevhen in Khust, in Subcarpathian Rus'. If they are here, then put them abroad and tell the government presidium about it" ${ }^{, 481}$. On January 2, 1939 Director of Police Yu. Biley informed A. Voloshyn that "Mykhailo Bazhanskyi, Alexander Khmeliovskyi, Dmytro Demchuk, Bohdan Fodchuk, Dmytro Ravich and Yevhen Vretsion were not reported by the local government. So far, it is not found where they are or anything about their activities" ${ }^{482}$. The Director of Police of Carpathian Ukraine knew that Y. Vertsion, better known in Transcarpathia as engineer Volianskyi, was a member of the General Staff of the Carpathian Sich. His signature was on most of the certificates issued to the Sich Riflemen who had completed the military training courses. This also applies to M. Bazhanskyi and O. Khmeliovskyi.

In the DAZO (State Archives of Transcarpathian Oblast') Funds there is Y. Vretsion's request to the Ministry of Internal Affairs for granting him a regional citizenship of Carpathian Ukraine: "Signed as Yevhen Vretsion engeneer-chemist from Prague Polytechnic, born on October 1, 1905 in Vynnyky, Lviv County, lives in the same place, the son of Omelyan and Maria of Banakhy, asks to grant him a citizenship of Carpathian Ukraine on the basis of the promise of a contract law in Khust... This person lives constantly in Khust and is working at an important position in Carpathian Sich from the first days of its existence. Already as a student he worked for the liberation of the Ukrainian nation, for which he was persecuted. When now, with the moment of the uprising of Carpathian Ukraine, new opportunities for work have opened for the nation and the state, he wants to give all his strength and experience to Carpathian Ukraine. And only for this case he asks to be granted this right, which is not now associated with privileges, but first and foremost with the obligations of which the undersigned is aware of $" 483$.

481 ДАЗО. Ф. 3. Оп. 1. Спр. 66. Арк. 3.

482 ДАЗО. Ф. 3. ОП. 1. Спр. 9. Арк. 2.

483 Карпатська Україна. Документи і матеріали. Хроніка подій. Персоналії: У двох томах. Том 1. Карпатська Україна. Документи i матеріали / Упорядники - О. Д. Довганич, О. М. Корсун, О. М. Пагіря; редакційна колегія: 
In almost every daily report of the commander of the Lviv Voivodeship, we can read reports of illegal transitions to the territory of Carpathian Ukraine ${ }^{484}$. The analysis of the documents leads to the conclusion that such transitions were most frequent in January - early February, 1939. Of course, not every attempt to cross the border was successful, but despite the fact that the Polish Border Service was already prepared for such a course of events, many Ukrainians from Galicia still came across the Carpathians. Polish police tried to identify the names of Ukrainians who had already secretly moved to Carpathian Ukraine. Among the reports of the Lviv commandant there is information from a Polish agent that "OUN members L. Koznarskyi, V. Stakhiv, E. Stakhiv stay in Transcarpathian Rus' and are members of Sich"485. As for E. Stakhiv, he was the commandant of the Carpathian Sich in Korolevo.

In order to prevent border crossings, the homes of citizens in Galicia, who were suspected of agitating and assisting defectors, were searched in Galicia. More often they gave negative results, but still the suspects were subject to prior arrest. Thus, in the village Velykyi Vylok, in the Sianky district, on suspicion of helping refugees four Ukrainians were searched on January 15, 1939. The search had a negative result. The detainees were sent to the prosecutor's office in Sianky ${ }^{486}$. Such actions were carried out until the middle of March, 1939. In the village Tarnava, on March 8, P. Mochko and L. Klym were detained for recruiting young people to the Carpathian Sich. Later, another 15 people were detained, and 2 carbines were taken from them ${ }^{487}$.

Cases of transfer Ukrainians to Poles by Czech gendarmes continued. In one of the documents it is mentioned: "On December 29, in Sianky, it became known that Ukrainian fugitives on the border are sent by Czechs to Medzilaborce, where they pay a fine or they are

М.А. Попович (голова), О. Д. Довганич (заст. голови), М. М. Вегеш, М. В. Делеган, В. К. Дрогальчук, О. М. Корсун, І. Ю. Коршинський, О. Ю. Кучерява, О. М. Пагіря, С. Д. Федака; редактор Д. М. Федака. Ужгород: ВАТ «Видавництво «Закарпаття», 2009. С. 172.

${ }^{484}$ ЦДІАУ у Львові. Ф. 205. Оп. 1. Спр. 498. Арк. 8

485 ДАЗО. Ф. 3. Оп. 1. Спр. 9. Арк. 57.

486 ДАЗО. Ф. 3. Оп. 1. Спр. 9. Арк. 160.

487 ДАЗО. Ф. 3. Оп. 1. Спр. 449. Арк. 35. 
arrested for 1-2 days, and then sent to the Polish border" ${ }^{\circ 88}$. However, among the Czechs there were those who sympathized with the Ukrainians. The aforementioned document states that one of the gendarmes advised them that otherwise they would "ask P. Lopata or V. Sushko, who live in Kalinov (Slovakia - Aut.), and who will direct them to the territory of Subcarpathian Rus" "489.

Brutal censorship on correspondence with Carpathian Ukraine was conducted in Poland. The location and activities of the fugitives in Transcarpathia were often found out because of the letters. All letters sent to the Galicians in Carpathian Ukraine were revised, and the phrases, which had the least political implication, were deleted. Thus, on January 5, 1939, the "Prosvita" society of the village Saiach Vyshnii of Drohobych district sent a greeting telegram to A. Voloshyn, in which they wished him "happy holidays and successes in working on the construction of the Ukrainian state". Drohobych Vice-Governor deleted part of the text beginning with the words "and successes..." This happened to a letter of S. Onydchak from Rudky, which was sent to the "Nova Svoboda" edition of January 12, 1939, with the following content: "Please, send the magazine "Nova Svoboda" to my address, "because I want to subscribe, but I do not know how"491. The Polish authorities could not and did not want the CarpathoUkrainian periodicals to be spreading in Galicia.

But still, Galician Ukrainians kept a close eye on the events in Carpathian Ukraine. First of all, thanks to Galician periodicals, sometimes - thanks to the leaflets and letters that came from there. There were facts when fugitives returned to Carpathian Ukraine for several days. In the message of the Voivodeship commander of Lviv from January 11, 1939 we can read: "On December 31, 1938 S. Pinchak, who left for Transcarpathia, was for 2 days with relatives in the village Dolzhychi, Sanok district, and then returned to Jawornyk. That same way D. Karlytskyi and S. Karlytskyi were in the

488 ДАЗО. Ф. 3. Оп. 1. Спр. 498. Арк. 8.

489 ДАЗО. Ф. 3. Оп. 1. Спр. 498. Арк. 5.

490 ДАЗО. Ф. З. Оп. 1. Спр. 498. Арк. 20.

491 ДАЗО. Ф. 3. Оп. 1. Спр. 498. Арк. 72. 
village Pryluky for several days" ${ }^{, 492}$. Another source of information about the events in Carpathian Ukraine for Galician Ukrainians was a separate, small-scale edition devoted to the history and culture of Transcarpathia, which began to appear in large numbers in Lviv in late 1938 - early 1939.

However, undoubtedly, the Polish authorities were most disturbed by the continuous illegal crossing of the Polish-Czech border. Today, it is difficult to determine the exact number of defectors. An analysis of the documents of the Court of Appeal of only one Lviv Voivodeship shows that in December 1938 the Polish police bodies identified the names of 35 Galicians who had fled to Carpathian Ukraine, in January 1939 - more than $80^{493}$. There were also cases of illegal transitions that were not recorded. The last attempt to cross the border in the reports of the commandant of the Lviv Voivodeship is dated March 10, $1939^{494}$.

It is interesting that the trials over defectors of the Polish-Czech border did not stop after the tragedy of Carpathian Ukraine. The new arrests and lawsuits that took place in Galicia became an echo of the Carpatho-Ukrainian events. At the end of March 1939, arrests were made among those few Sich Riflemen who returned to Poland after the tragedy of Carpathian Ukraine. So, on March 25 in the village Sokolyky of Turka County, three Ukrainians, who were crossing the Polish-Czech border illegally, were detained ${ }^{495}$. The lawsuits were preceded by a lengthy investigation. The sentence to the detained A. Khomiosiak, B. Prokop and M. Levytskyi was announced only on April 28, $1939^{496}$. In the Funds of the Central State Historical Archive in Lviv there are letters from the district prosecutor in Berezhany to the Prosecutor of the Court of Appeal in Lviv about the course of the investigation, the content of the interrogations and the sentence itself $^{497}$. Three types of punishment were applied to prisoners:

\footnotetext{
492 ДАЗО. Ф. 3. Оп. 1. Спр. 498. Арк. 38.

493 ЦДІАУ у Львові. Ф. 205. Оп. 1. Спр. 498. Арк. 12-110.

494 ДАЗО. Ф. 3. Оп. 1. Спр. 499. Арк. 50.

495 ЦДІАУ у Львові. Ф. 205. Оп. 1. Спр. 499. Арк. 128.

${ }^{496}$ ЦДІАУ у Львові. Ф. 205. Оп. 1. Спр. 1095. Арк. 2, 6.

${ }^{497}$ ЦДІАУ у Львові. Ф. 205. Оп. 1. Спр. 1095. Арк. 2, 6, 10.
} 
imprisonment, loss of civil rights, police surveillance ${ }^{498}$. Usually, prisoners were sentenced to a term of six months to eight years. Among the sentences are the following: agitation for crossing the border, assistance in crossing the border, attempts to cross the border, illegal stay in Carpathian Ukraine ${ }^{499}$. The list of convicts from April 1 to June 30, 1939 for belonging to the OUN, compiled by the Prosecutor's Office of the Court of Appeal in Lviv, contains the names of 24 Ukrainians whose sentences are related to the illegal crossing of the Polish-Czech border ${ }^{500}$. Giving an assessment to the Carpathian Sich, P. Stercho noted that in its development "our brothers from Galicia, Bukovyna, Volyn, Chelm Land and Lemkivshchyna, in particular members of the OUN, were an important factor",501.

Galicians took an important part in the defense of Carpathian Ukraine. Vasyl Boychuk, Tymko Prots, Vasyl Sabliuk, Zenon Kossak (Tarnavskyi), Stepan Fihura, Ivan Mykhailiuk, Moniuk, Dulka, Kushnir, Meleshko, Orlovych and many others were killed during the fights or were tortured. Colonel M. Kolodzinskyi, who acted as the last Chief of Staff, refused to accept the Hungarian ultimatum to end the fight. "There is no word "capitulation" in the dictionary of the Ukrainian nationalist. A stronger enemy can defeat us in the battle, but he can never put us on our knees!" - such was M. Kolodzinskyi's answer. After a fight with the Horthys' soldiers in Krasne Pole on March 15, 1939, he and his comrade Z. Kossak-Tarnavsky retreated towards Solotvyno.

So, M. Kolodzinskyi (Colonel Huzar) is the most legendary figure in this segment of Transcarpathian history ${ }^{502}$. He was born on July 26, 1902 in the village Potochyska of Horodenka district, Stanislaviv region, in a peasant family. He graduated from the Kolomyia Gymnasium (1924), the Faculty of Law of the University of Lviv and

\footnotetext{
${ }^{498}$ ЦДІАУ у Львові. Ф. 205. Оп. 1. Спр. 499. Арк. 8.

${ }^{499}$ ЦДІАУ у Львові. Ф. 205. Оп. 1. Спр. 499. Арк. 2.

${ }^{500}$ ЦДІАУ у Львові. Ф. 205. Оп. 1. Спр. 499. Арк. 2-21.

501 Стерчо П. Карпато-Українська держава: 3 історії визвольної боротьби карпатських українців у 1919-1939 роках. Торонто, 1965. С. 98.

502 Вегеш М. Полковник Михайло Колодзінський-Гузар у Карпатській Україні. Визвольний илях. Кн.8. 1993. С.955-957.
} 
the Officer's School of the Polish Army (1928). From 1922 he was a member of the Ukrainian Military Organization, and later - a military referent of the first Regional Executive in Western Ukrainian Lands (1929). In January 1932 M. Kolodzinskyi was arrested in Lviv by the Polish police for speaking to the youth with a lecture "Nationalists and Military Education" and had been in prison for over a year. Thanks to published works "Ukrainian military doctrine", "Military situation and strategic importance of Transcarpathia", "Ivan Bohun", "Polish uprising of 1863", "Railway communication in the USSR", "Struggle of the Italians for independence and unity", "Partisan war" he has established himself as one of the prominent military theorists in Europe ${ }^{503}$.

The military-theoretical works of M. Kolodzinskyi proved that a military theorist appeared in Ukraine, before whom a good military career was opening. M. Kolodzinskyi was one of the first to appear in Transcarpathia and was included into the General Staff of the Carpathian Sich. V. Grendzha-Donsky called Colonel M. Kolodzinskyi (Huzar) "the brain of Sich" "504. And he really was. Of the large number of emigrants from Carpathian Ukraine, the eyewitnesses collected the best memories first of all about Huzar. "His high figure has always been impressive to me," V. GrendzhaDonsky wrote, "now I just adore him. Although he walks in civilian clothes, it is immediately evident that he is a warrior... He breaks hatred against enemies, his calm, balanced face is the expression of a brave soul, those firm features reflect boundless, undaunted courage..., ${ }^{, 505}$.

Simultaneously with M. Kolodzinskyi, the Ukrainian political and military figure Zenon Kossak came to Transcarpathia. He was born on April 1, 1907 in Drohobych, now Lviv oblast'. While studying at a

\footnotetext{
503 Федина В. Михайло Колодзінський-Гузар і Карпатська Україна. Carpatica Карпатика. Вип. 7. Ужгород, 2001. С. 223-241; Федина В. Полковник Михайло Колодзінський-Гузар - борець за незалежність Карпатської України. Науковий збірник Товариства «Просвіта» в Ужгороді. Річник IV(XVIII). Ужгород, 2000. C. 93-96.

${ }^{504}$ Гренджа-Донський В. Щоденник. Твори. T.VIII. Вашингтон, 1987. С. 70.

505 Гренджа-Донський В. Щастя і горе Карпатської України: Щоденник. Мої спогади / Ред. Д.М. Федака. Ужгород: ВАТ «Видавництво «Закарпаття», 2002. С. $187-188$.
} 
local gymnasium, he was elected chairman of the "Organization of Higher Classes of Ukrainian Gymnasiums". In 1926-1928 he studied at the Law Faculty of Lviv University, actively cooperating with such editions as "Student Bulletin", "Lviv Scientific Bulletin", "Bulletin". Z. Kossak passed the way from a member of the Leadership of the Union of the Ukrainian Nationalist Youth (1928), a member of the OUN (1929), a referent of the OUN Regional Executive in Western Ukraine (1929) to a deputy of combatant R. Shukhevych (1930). The UVO combat group in Drohobych, created by him, organized a number of terrorist acts against individual representatives of the Polish authorities in Boryslav, Truskavets and Horodenka (19311932). In June 1933 a Polish court sentenced Z. Kossak to 7 years in prison for his activities in the OUN. His final sentence was announced on January 31, 1934 in Lviv -8 years in prison including the investigation period. He served his sentence in the prisons of Lviv and Wronki (Poznan Voivodeship of Poland), where he completed the work "44 Rules of Life of a Ukrainian Nationalist" (1934-1938). Also important is the fact that Z. Kossak participated in the development of escape plan of S. Bandera from prison in Wronki in June-September 1938, which resulted in his arrest and detention until the end of November $1938 .^{506}$.

Z. Kossak arrived in Carpathian Ukraine in December 1938 and operated under the pseudonym Tarnavskyi. In the Carpathian Sich he was assigned the rank of lieutenant. Throughout the existence of Carpathian Ukraine, Z. Kossak headed the sub-department of ideology in the department of press and propaganda, headed by

\footnotetext{
506 Пирович В. Діяльність Зенона Коссака-Тарнавського в Карпатській Україні. Carpatica - Карпатика. Вип.7. Ужгород, 2001. С.242-251; Пирович В. Зенон Коссак-Тарнавський (1907-1939). Карпатська Україна. Документи $i$ матеріали. Хроніка подій. Персоналї: У двох томах. Том 2. Карпатська Україна. Хроніка подій. Персоналії / Упорядник С. Д. Федака; редакційна колегія: I. І. Качур (голова), М. М. Вегеш, О. Д. Гаврош, М. В. Делеган, В. І. Дмитрук, О. Д. Довганич, В. К. Дрогальчук, О. М. Корсун (заст. голови), І. Ю. Коршинський, Ю. В. Мойш, М. В. Олашин, О. М. Пагіря, С. Д. Федака; редактор Д. М. Федака. Ужгород: ПРАТ «Видавництво «Закарпаття», 2010. С. 387-391; Політична історія України. ХХ ст.: У 6 т. / Редкол. І. Ф. Курас (голова) та ін. Т. 5: Українці за межами УРСР (1918-1940). Керівник тому В. П. Трощинський. К.: Генеза, 2003. 720 с.
} 
V. Komarynskyi, as an ideological referent he was publishing in the newspaper "Nova Svoboda". He conducted direct military training in the Carpathian Sich: he was an instructor in the undergraduate courses, as well as in the women's departments of medicine and secret service. It was on the initiative of Z. Kossak on February 19, 1939 that the Second Sich Congress was held in Khust.

During the bloody clashes of March 13-14, 1939 between the Sich and the Czech army, M. Kolodzinskyi defended the Sich hotel. He stopped the resistance only after the order of A. Voloshyn. Participant in the fights, Galician Levko Kris, described the last moments of resistance: "Two minutes later they saw the white flag again on the other side and went with it: Prevuznyk - Minister of Internal Affairs and Slovak Lieutenant Commander Parchani. Ours let them come to the barricade and they stated that it was Mr. Prime Minister's desire to lay down their weapons. The commander of the defense (M. Kolodzinskyi - Aut.) said that we do not give weapons for the enemies. Then they began to persuade us that there was no point in defending, because in a short time they would kill us like mice. The commandant's response was: "No one will forbid us to die heroically!". The Minister of Internal Affairs, Mr Perevuznyk, said that Mr. Prime Minister is talking to Prague on the telephone and that difficult times are coming for our people and that there is no sence to put our lives heroically here, in a minute they would be needed in another place... When I came to Prime Minister's room, I put my revolver on the table and said that I can only give my weapon to him, and to no one else. He ordered all the Sich Riflemen to lay down the weapons that the Riflemen had and carry it to his house" $" 507$.

M. Bazhansky described the above mentioned events interestingly. He did not hide that "at night from March 13 to March 14, the Carpathian Sich Riflemen prepared an uprising"508. As mentioned above, M. Bazhanskyi most often saw A. Voloshyn these days. From his memoirs it is clear that M. Kolodzinskyi was not permanently in the hotel. "President Avgustyn Voloshyn negotiated with the Czechs," wrote M. Bazhanskyi. "Father of the Carpathian people, as

\footnotetext{
507 Заповіт Срібної землі. Карпатська Україна в боротьбі за незалежність. Львів: «Світ», 2001. С. 56-57.

${ }^{508}$ Бажанський М. Мемуарна мозаїка. К.: Критика, 1998. С. 87.
} 
he was called at that time, didn't want the blood of young people to be spilled. He was driving in the car with Colonel Kolodzinskyi from one Czech government building to another. From gendarmerie to military command. Truce was finally concluded. The Czechs had to release all those arrested, had to hand over all governments, barracks and weapons. However, the Czechs did not fulfil the agreement in all localities. In part, this was only done by General Svatek on his own in Svalyava region" ${ }^{, 09}$. As a result of the fighting, both sides suffered casualties, many people were injured. In literature there are some differences concerning this issue. The authors give different accounts of the number of dead during the fighting of March 13-14, 1939. Although the information is different, it is known that the Sich Riflemen were killed far more than the Czech soldiers. According to V. Kerechanyn's estimates, 40 riflemen were killed and 50 were injured $^{510}$.

${ }^{509}$ Ibid. C. 89.

510 Книга пам'яті України. Закарпатська область: У 2-х томах. Т. 2./ Гол. редколегії В. Керечанин. Ужгород: Вид-во «Карпати», 1998. С. 58; Керечанин В. В умовах окупації і боротьби. Книга Памяті Украӥни. Закарпатська область: У 2-х томах. Т. 2. Ужгород: Карпати, 1998. С. 66-70; Керечанин В. Віденський арбітраж - переділ Закарпаття. Книга Памяті Украӥни. Закарпатська область: У 2-х томах. Т. 2. Ужгород: Карпати, 1998. С. 30-36; Керечанин В. Готуючись до оборони краю. Книга Памяті Украӥни. Закарпатська область: У 2-х томах. Т. 2. Ужгород: Карпати, 1998. С. 45-55; Керечанин В. Карпатські січовики в боях 3 угорськими військами. Книга Памяті України. Закарпатська область: У 2-х томах. Т. 2. Ужгород: Карпати, 1998. С. 55-63; Керечанин В. Наступ уряду Угорщини за перегляд Тріанонського договору. Книга Памяті Украӥни. Закарпатська область: У 2-х томах. Т. 2. Ужгород: Карпати, 1998. С. 15-18; Керечанин В. Тривожні роки. Книга Памяті Украӥни. Закарпатська область: У 2-х томах. Т. 2. Ужгород: Карпати, 1998. С. 13-15; Керечанин В. Угорсько-польський тандем у боротьбі за спільний кордон. Книга Памяті Украӥни. Закарпатська область: У 2-х томах. Т. 2. Ужгород: Карпати, 1998. С. 24-29; Керечанин В. Угорщина відновила «малу війну». Книга Памяті Украӥни. Закарпатська область: У 2-х томах. Т. 2. Ужгород: Карпати, 1998. С. 36-39; Керечанин В. Шлях угорським завойовникам торували терористи. Книга Памяті Украӥни. Закарпатська область: У 2-х томах. Т. 2. Ужгород: Карпати, 1998. С. 18-24; Керечанин В., Довганич О. «Вода в Тисі була червоною від крові ...». Книга Памяті України. Закарпатська область: У 2-х томах. Т. 2. Ужгород: Карпати, 1998. C. 63-65. 
It is necessary to agree with the modern researcher V. Fedyna that there is no reliable information about the further fate of M. Kolodzinskyi, since none of the people in his department escaped. In the memoirs of staff officers and Sich Riflemen it was noted that the last time Kolodzinskyi was seen before the departure of the main Sich forces, and the authors' information about the further fate of Huzar's department coincides with the official Hungarian reports. V. Fedyna shares the opinion of M. Bazhanskyi, who noted that it is very difficult to believe that Kolodzinskyi accepted death on his feet, when he was unable to walk. As for the photographs, they were not expressive enough to claim that those were really Kolodzinskyi and Kossak. As for the Sich Riflemen, their names were given quite illiterately, and in some cases were not true. According to him, there was a fierce fight between Colonel Huzar's department and the Hungarians, who were "just tortured animalily", and all this information was disseminated in order to reassure the Hungarian population and not to come up with the truth that hundreds of "valiant" honveds could not defeat 15 tired and wounded Sich Riflemen ${ }^{511}$.

I. Stebelsky tried to find out the fate of his fellow-countrymen, who had previously left Carpathian Ukraine. He learned about them only in the summer of 1939, when the former Khust Sich Riflemen arrived in the Austrian Alps for training in the ranks of the anti-Polish legion, which was forming there. "I learned from them," I. Stebelsky wrote, "that Mykhailo Andrushkiv ("Hanzio") was killed by a Hungarian machine gun during the defense of the General Command of the "Carpathian Sich". The day before, a brave Burun fell from the Czech machine-gun. The survivals of the Sich Riflemen, retreating with the fights from Khust controlled by the Hungarians, just as usual

\footnotetext{
511 Федина В. Полковник Михайло Колодзінський-Гузар - борець за незалежність Карпатської України. Науковий збірник Товариства «Просвіта» в Ужсгородi. Річник IV(XVIII). Ужгород, 2000. С.95-96; Федака С. Карпатська Січ у свідченнях очевидців. Карпатська Украӥна - етап українського державотворення: історія $i$ сучасність. Матеріали наукової конференції, присвяченої 80-річчю проголошення незалежності Карпато-Української держави і 145-річчю від дня народження видатного закарпатського політика i громадсько-культурного мислителя Августина Волошина. Ужгород, 2019. C. $36-41$.
} 
in such a desperate situation, in chaos and in a panic due to the difference of views, divided into three groups and retreated in different directions. The strongest group - with centenarians S. Sulatitskyi and Volianskyi - retreated to Velyky Bychkiv in the direction of Romania. The second, weaker one - led by Colonel Mykhailo Kolodzinskyi, our countryman Zenko Kossak - departed to the north in the wide Carpathian Mountains. Dorko Lata and Mykola Andrushkiv also retreated along with this group. The fate of this group is completely unknown because none of them survived. It is speculated that it was trapped in a Hungarian ambush and the survivors were passed on to the Poles who shot them at the border. The fate of the third, smallest, group consisting of Romko Tatarskyi and Vlodko Andrushkiv, had to retreat northwestward toward Slovakia. No one could say what happened to it. In 1940 I learned that they had both fallen into Polish hands and been locked in a concentration camp in the Bereza Kartuska, from which, miraculously, thanks to the German-Polish War, they were released. Both returned home, where they were caught by the Bolsheviks, who at that time have occupied our western Ukrainian lands. By some miracle, I do not know exactly, Romko Tatarskyi escaped, and Vlodko Andrushkiv, apparently mainly due to his stay in Carpathian Ukraine, was soon arrested by the NKVD and disappeared forever" ${ }^{, 512}$.

About the terrible crimes of the terrorist group "Sabot Chopot" in the village Yasinia was told by witness Danylo Popiuk, a cemetery keeper: "In 1939, before the Hungarian invaders, a terrorist group was organized in the village of Yasinia..., which together with Hungarian terrorists took 18 Ukrainians, including 4 women, by car to the passover. Their hands were tied with barbed wire, their eyes were gouged out, ears, noses cut off, fingernails ripped, their tongues cut off and their feet were sawed in three places. Those, who were weak, died during the abuse, and those, who were still alive, were then killed and I was ordered to bury them in the ground... Three days later I was sent to bury another 8 men, also killed on the passover" ${ }^{, 513}$.

512 Стебельський I. Шляхами молодості й боротьби. Спогади. Статті. Листування. К.: «Смолоскип», 1999. С. 36-37.

513 ДАЗО. Ф. 2558. Оп. 1. Спр. 202. Арк. 44. 
In Volove, Hungarian terrorists shot five patriots led by local Sich commander Stepan Fihura. Eyewitnesses said they found a bloody shirt under the straw hat of S. Fihura, in which there were blood clots. The villagers stated that it was a shirt of S. Fihura. Horthy's supporters, after executing the death sentence, returned back in high spirits: there was something to take. They cut off a finger with a wedding ring from one of the killed and knocked out the golden teeth from another one ${ }^{514}$. Hungarians shot Lieutenant F. Tatsynets and four Galicians in the Soimy Forest near Volove ${ }^{515}$.

Recently, in the historical literature there are often statements that there were numerous conflicts between the Transcarpathians and the Galicians. Such a statement is advantageous for researchers standing in Ruthenian positions, trying to prove the Transcarpathian ceparate identity. M. Makara in his monograph, which has nothing to do with the coverage of historical processes in Transcarpathia on the eve of World War II, wrote that in 1938-1939, "the local statehood was designed and dictated from Berlin by the hands of nationalist emigration, the efforts of which transformed the autonomous Subcarpathian Rus' into Carpathian Ukraine, which, without the knowledge of the majority of the population, was to become the "germ of an independent united Ukraine" under the slogans of national idea ("nation above all"), national exclusivity, messianism, which was an illusory affair, or rather an adventurous one, in those circumstances" ${ }^{916}$. He is supported by I. Pop, calling Carpathian Ukraine "the provincial theatrical scene of the Romantic era"

V. Grendzha-Donsky wrote in his diary "Happiness and grief of Carpathian Ukraine": "Whispers about some conflicts in "Carpathian Sich" continue, but this is not true. It is true that there are small misunderstandings between us - autochthons and Galicians, for the very reason that the Galicians have been in a very radical way against

\footnotetext{
514 Вегеш М.М., Горват Л.В. Карпатська Україна 1938-1939 років в портретах. Ужгород, 2000. С. 72.

515 Ibid. C. 43-44.

516 Макара М.П. Закарпатська Україна: шлях до возз'єднання, досвід розвитку (жовтень 1944 - січень 1946 рр.). Ужгород, 1995. С. 101.

517 Поп И. Энциклопедия Подкарпатской Руси. Ужгород: Издательство В. Падяка, 2001. С. 43-44.
} 
Poland, and we are trying to slow them down a bit. The Galicians would like to cause an incident, hoping that Germany would intervene in it and release Galicia. But this is a gambling game, we can lose Carpathian Ukraine as well, and nothing will happen with Galicia... Little Carpathian Ukraine will not release Western Ukraine, it will not be able to release, then what is the reason for such a dangerous neighbor to touch..." $" 518$. I. Hutsul in his memoirs "The Last Hundred" also wrote about the wanderings of the Galicians and their tragic fate $\mathrm{f}^{519}$.

Particularly appalling are the testimonies of the execution of the riflemen in 1939, when the defenders of Carpathian Ukraine acquired the status of prisoners. One of the places of mass executions of the riflemen can be called Veretsky Pass. Witnesses to those tragic events prove that the mass executions were carried out by both Hungarian and Polish troops. Thus, one of the witnesses F. Holianych said that after the Hungarians handed over hundreds of captured Sich Riflemen (mostly Galicians) to the Polish military, they had been shot the next day. Hundreds and hundreds of bodies of defenders of Carpathian Ukraine have been found at other places ${ }^{520}$. Many Galicians were shot by Poles after the defeat of Carpathian Ukraine. Six unknown patriots, whose names have not yet been found out, were shot on Verechansky Pass $^{521}$. A contemporary Ukrainian researcher, H. Demian, wrote that "four boys, who were returning from Transcarpathia sometime in late March 1939, were killed by Poles in

\footnotetext{
${ }^{518}$ Гренджа-Донський В. Щоденник. Твори. Т.VIII. Вашингтон, 1987. С. 158.

519 Заповіт Срібної землі. Карпатська Україна в боротьбі за незалежність. Львів: «Світ», 2001. С. 125-126.

${ }^{520}$ Вони боронили Карпатську Україну: Нариси історії національно-визвольної боротьби закарпатських українців / М.М. Вегеш, М.В. Делеган, О.Д. Довганич та ін. [Відп. ред. М.М.Вегеш]. Ужгород: Карпати, 2002. С. 162-164; Сфремів С. Бої 14-15 березня 1939 року на Карпатській Україні. Ужгород: Видавництво Гражда, 2009. 100 с.; Сфремів С. Бої 14-15 березня на Карпатській Україні. 3a державність. Матеріали до історії війська українського. Торонто: Український воєнно-історичний інститут, 1966. Т.ІІ. С. 128-165; Єфремів С. Бої на Карпатській Україні 14-15 березня 1939 року. Івано-Франківськ: «Лілея-НВ», 2019. 96 с. Заповіт Срібної землі. Карпатська Україна в боротьбі за незалежність. Львів: «Світ», 2001. 192 с.

521 Літопис нескореної України: Документи, матеріали, спогади / Відп. ред. Я. Лялька. Книга 1. Львів: «Просвіта», 1993. С. 348.
} 
Luzhok ${ }^{, 522}$. Eyewitness and active participant in the defense of Carpathian Ukraine, M. Chyrskyi told about the execution of 44 Galicians" ${ }^{, 523}$.

On March 16, 1939, the Hungarian troops marched on the Polish border in the Beskyd region, and on March 19, the Hungarian and Polish troops marched near Sianky and Vorokhta ${ }^{524}$. During the aggression, Hungarian planes scattered "greeting leaflets" near the Polish border, which ended with the words: "Let Poland and Hungary live forever" ${ }^{525}$. And what happened in Galicia? Ukrainian political parties, which had representatives in the Polish Senate, tried to cast their votes in defense of Carpathian Ukraine. On March 17, 1939 Senator Tvordnian (UNDO), on behalf of the UPR, tried to make a statement about the events in Carpathian Ukraine, but "the speaker was not given a word" ${ }^{\text {"26 }}$. After the fall of Carpathian Ukraine, mourning services in the churches were held throughout Galicia. On March 18, the St. George's Cathedral in Lviv held a prayer service for the fallen Sich Riflemen, attended by about 400 people. After the church service there was a meeting under the slogans "Get away with the Magyars", "Get away with the Poles". The police dispersed the demonstrators ${ }^{527}$. District Attorney of Stanislav in his report informed about these measures on April 18, $1939^{528}$.

Thus, the Ukrainians of Eastern Galicia with great enthusiasm met the news of the granting of autonomous rights to Transcarpathia, and subsequently the proclamation of an independent Carpatho-Ukrainian state. Their support for the national liberation competitions of the Transcarpathian Ukrainians resulted in numerous demonstrations and protests against the expansionist plans of Poland and Hungary to create a common border. Starting in October 1938, the illegal crossing of the Polish-Czech border by young men and women of Galicia to Carpathian Ukraine began. For the most part, they were

\footnotetext{
522 Ibid.

523 Заповіт Срібної землі. Карпатська Україна в боротьбі за незалежність. Львів: «Світ», 2001.

524 Діло. 1939. 17 березня.

525 ЦДІАУ у Львові. Ф. 205. ОП. 1. Спр. 499. Арк. 99.

526 Діло. 1939. 19 березня.

527 ЦДІАУ у Львові. Ф. 205. Оп. 1. Спр. 499. Арк. 89.

${ }^{528}$ ЦДІАУ у Львові. Ф. 205. Оп. 1. Спр. 879. Арк. 177.
} 
spontaneous. The OUN and its Leadership have taken a vague position on the need to cross the border. Perhaps this was due to the fact that the OUN leaders did not believe in the victory of the idea of an independent Ukraine in the Carpathians. It was at the end of the 1930s that there was a split in the Ukrainian Nationalist Leadership, which is why, as a rule, members of the OUN of Melnyk's wing appeared in Carpathian Ukraine. Galician Ukrainians were in great danger when they were crossing the border. They could have been detained by Polish border guards or turned back by Czechoslovakian. In any case, the Galician youth appeared in a Polish court. Archival documents show that the Polish government closely followed the events, was well informed, often addressing the Czechoslovak government with notes of protest. In the vast majority of cases, the Ukrainian authorities stated that the Polish notes were untrue and had no grounds. The authorities of Czechoslovakia have ambiguously treated those who crossed the border. There were both a favorable attitude and the extradition of Galicians to the Poles. The vast majority of Galician Ukrainians actively participated in the development of Carpathian Ukraine, joining the ranks of the Carpathian Sich. Illegal border crossings continued until early March 1939, and lawsuits in Poland over defectors took place during AprilJune. The illegal crossings of the Polish-Czech border by the Ukrainians in Eastern Galicia in 1938-1939 testified to their solidarity with the national liberation struggle of the Transcarpathians. 